\title{
Nutritional treatment for leagnous conjuntivitis: case report and literature review and case report
}

\author{
Terapia nutricional proposta para conjuntivite lenhosa: \\ estudo de caso e revisão de literatura
}

Mariana Granito', João Maria Ferreira²

\begin{abstract}
Ligneous conjunctivitis is the result of a rare inherited autosomal recessive disorder, the plasminogen deficiency. This presents chronic symptoms such as growth spongiosa meat, tearing, mucous discharge and ocular reddening accompanied by ligenous pseudomembranes $(P L)$ coat the inside of the tarsal conjunctiva. The literature presents some treatments, but none of them reached a cure. The nutritional therapy addressed in this study is a combination of nutrients within the limits of daily intake, based on orthomolecular nutrition, aimed at increasing functional plasminogen rate, and the consequent reduction of symptoms associated with their disability. It was noted disappearance of the symptoms associated and a $25 \%$ increase in the functional plasminogen. A $25 \%$ increase in plasminogen dosage may not be highly significant, but it opens up a support for further study, as already presented reduction of symptoms of the patient.
\end{abstract}

Keywords: Conjunctivitis/etiology; Plasminogen/deficiency; Eye disease; Nutrition therapy; Case reports

\section{ReSUMO}

A conjuntivite lenhosa é resultante de um raro distúrbio autossômico recessivo hereditário, a deficiência de plasminogênio. Esta apresenta sintomas crônicos, como lesões conjuntivais membranosas características, inicialmente finas e com a persistência da inflamação evoluem se tornando esbranquiçadas, espessas e enrijecidas, lacrimejamento, secreção mucosa e hiperemia ocular acompanhados de espessas pseudomembranas lenhosa (PL) que recobrem a parte interior da conjuntiva tarsal. A literatura apresenta alguns tratamentos, entretanto nenhum deles alcançou a cura da doença. A terapia nutricional abordada neste estudo trata-se da combinação de nutrientes dentro dos limites estabelecidos para ingestão diária, baseada na nutrição ortomolecular, visando ao aumento da taxa de plasminogênio funcional, e a consequente redução dos sintomas associados à sua deficiência. Notou-se o desaparecimento de sintomas associados e redução do crescimento da PL, e também um aumento de $25 \%$ do plasminogênio funcional. Um aumento de $25 \%$ na dosagem de plasminogênio pode não ser altamente significativo, mas abre um respaldo para maiores estudos, pois já apresentou minimização dos sintomas da paciente.

Descritores:: Conjuntivite/etiologia; Plasminogênio/deficiência; Oftalmopatias; Terapia nutricional; Relato de casos

\footnotetext{
1 Nutritionist; Master's Degree in Medical Sciences from UFF

2 Medicine School, Centro Universitário Serra dos Órgãos (UniFeso), Teresópolis, RJ, Brazil.

Study carried out at Centro Universitário Serra dos Órgãos (UniFeso), Teresópolis, RJ, Brazil.

The authors declare no conflicts of interests.

Received for publication 18/07/2015 - Accepted for publication 11/12/2015
} 


\section{INTRODUCTION}

$\mathbf{L}$ eagnous conjunctivitis is a rare autosomal recessive disease. Its diagnosis is based on clinical and histological data, and eventually on positive family history. The clinical findings usually are: chronic tearing, conjunctival hyperemia, growth of leagnous pseumembranes (PL) in the conjunctiva and/ or other mucosal sites in the body, possibly in combination with milium colloid or obstructive congenital hydrocephalus. ${ }^{(1-3)}$

It is caused because there is a deficiency of plasminogen, it means that there is accumulation of mucus threads and fibrin membranes, stimulating fibroblasts and inflammatory cells of the ocular surface (but can also accumulate in other surfaces such as the gums, causing leagnous gingivitis. ${ }^{(2,3)}$

\section{Case Report}

\section{Patient history}

Patient C.G.C.P., 13 years old, female, diagnosed at 3 years old with leagnous conjunctivitis due to a symptomatic homozygous deficiency of plasminogen (Functional Plasminogen $20 \%$; Reference threshold according to the medical diagnostic laboratory: $70 \%$ to $140 \%$ ). Concomitant to the disease, the same featured low immunity with frequent appearance of skin infections due to atopic dermatitis, and in the respiratory tract, constant rashes, excessive production of secretions in the mucosa of the eyelid, with growth of leagnous pseudomembrane (PL).

Since the beginning of the lesions, around 2 years of age, the same underwent surgical procedures several times for the removal of the PL, which were recurrent weeks after removal. This process was carried out as reported in the present study, without the use of the specific medication described. She only used anesthetic eyedrops in the post-operative period, and topical use of loteprednol etabonate ( $2 \mathrm{mg}$ applied $3 \mathrm{x} /$ day). The treatment with about $1 \mathrm{~g} /$ day of calf thymus acid lysate was carried out, equivalent to $20 \mathrm{mg}$ of the active ingredient thymomodulin in an attempt to improve the immune system without great results.

Due to ignorance about the disease by all health professionals consulted, for nearly four years no specific treatment was used for the disease, even after its diagnosis.

At age 6, she began a treatment using autologous serum, where the paternal blood was extracted and centrifuged, and the plasma decanted was stored in sterile packaging of the eyedropper type and frozen for topical use on PL. It seemed to alleviate the symptoms of mucus production and hyperemia. It was used for 4 years, but with no significance in the treatment. Concomitant to the use of the serum, the removal surgery was performed at intervals of about 3 months.

At age 10, in the year 2011, the patient began the treatment reported in the present study. A nutritional therapy was developed by a professional Nutritionist according to studies carried out in respect of each nutrient and their function. The surgical removal was made by an ophthalmologist in the operating room at Hospital São José, in Teresópolis. The histopathological exam was made by the laboratory of the same hospital where the surgery was performed.

\section{Nutritional therapy}

The nutritional therapy applied was divided into 3 phases. Phase 1 addresses the nutritional complementation with $1 \mathrm{~g}$ of collagen, collaborating on the protein structure, and $1 \mathrm{~g}$ of colostrum, for a better immune balance. This phase lasted a year, and was followed by phase 2 . In this second phase $100 \mathrm{mg}$ of $\mathrm{CoQ} 10$, magnesium and calcium were administered as proposed by the orthomolecular practice ${ }^{[3]}$.

And in both phases, the reduction of lactose was proposed for the improvement of rash, while the other nutrients were used directly for the treatment of plasminogen deficiency, the cause of leagnous conjunctivitis. ${ }^{[3]}$. The treatment was drawn up according to the table below:

\section{Table 1}

Administration of orthomolecular nutrition treatment for deficiency of plasminogen

\begin{tabular}{lcc}
\hline Nutrient administered & Daily dose & Phase \\
\hline Collagen & $1 \mathrm{~g}$ & 1 \\
Colostrum & $1 \mathrm{~g}$ & \\
Coenzyme Q10 & $200 \mathrm{mg}$ & \\
Magnesium & $200 \mathrm{mg}$ & 2 \\
Calcium & $200 \mathrm{mg}$ & \\
\hline
\end{tabular}

Reduction of lactose

Milk exemption

1and 2

\section{Nutritional therapy for food}

Three years after orthomolecular therapy, the functional nutritional therapy began concomitantly to promote antiinflammatory action, focusing on bioactive compounds.

The elements shown in table 2 were added to the diet.

Table 2

Administration of functional nutrition treatment for deficiency of plasminogen

\begin{tabular}{lcc}
\hline Element administered & Dose & Desired compound \\
\hline Olive oil & $7 \mathrm{~g} 2 \mathrm{x} /$ day & Omega 9 \\
Full red grape juice & $150 \mathrm{ml} 1 \mathrm{x} /$ day & Resveratrol \\
Oats & $2 \mathrm{x} /$ day & Polyphenols \\
Flaxseed & $1 \mathrm{x} /$ day & Polyphenols \\
\hline
\end{tabular}

In addition to the administration of nutrients described above, the consumption of foods rich in saturated fats like fried foods, chocolates, yellow cheese, etc., was reduced. Propolis was also administered in the form of topical application on the gums 1x day.

\section{Nutritional therapy for complementation}

A supplement of vitamins and minerals was administered, besides some bioactive compounds by manipulated capsules administration (by compounding pharmacy properly regularized). The compounds administered are specified in table 3 
Table 3

Administration of nutrition complement for deficiency of plasminogen

\begin{tabular}{lr}
\hline Element administered & Daily dose \\
\hline Omega 3 & $14 \mathrm{mg}$ \\
Iron & $500 \mathrm{mg}$ \\
Turmeric & $2,4 \mathrm{mcg}$ \\
Vitamin B12 & $30 \mathrm{mg}$ \\
Zinc & $500 \mathrm{ui}$ \\
Retinol & $50 \mathrm{mg}$ \\
Acid & $100 \mathrm{mg}$ \\
Magnesium & $200 \mathrm{mg}$ \\
Calcium & $800 \mathrm{mcg}$ \\
Copper & $60 \mathrm{mcg}$ \\
Selenium & $400 \mathrm{mg}$ \\
Alpha Tocopherol & $5 \mathrm{mg}$ \\
Thiamin & $20 \mathrm{mg}$ \\
Nicotiamide & $2 \mathrm{mg}$ \\
Pyridoxine & $5 \mathrm{mg}$ \\
Riboflavin & $3 \mathrm{mg}$ \\
Calcium pantothenate & $300 \mathrm{mcg}$ \\
Folic acid & $400 \mathrm{mg}$ \\
Turmeric & \\
& 300 \\
\hline
\end{tabular}

The surgical excision of the PL is necessary due to the rapid growth, leading consequently to the trauma of the corneas, although it is known that relapses are inevitable. However, we noticed significant reduction of growth of PL, having extended the period between surgeries, from 3 months to 1 year, on average. After physical examination, we observed the disappearance of recurring rashes and skin infections. It is believed to be due to relief of lactose and the use of antiinflammatory and antioxidant nutrients.

Regarding biochemistry, there was an increase of $25 \%$ in the dosage of the patient's functional plasminogen, that is, at the onset of treatment the patient presented $20 \%$ of serum plasminogen, and three years after the onset she presented $25 \%$ in the total dose, representing an increase of $25 \%$.

It should be noted that there was no treatment concomitant to the one described.

\section{Surgical treatment}

When PLs are bothersome to the patient, they are surgically removed. It is usually necessary when PLs grow, assaulting the cornea (figures 1 and 2), but not generating direct injuries to this. A surgical debridement (Figure 3 ) of the PLs located on the tarsal conjunctiva of the upper and lower eyelids of both eyes was carried out. For this removal, the patient is subjected to the process of local anesthesia associated to assisted sedation.

After removing the tissue, the conjunctiva cauterization is made with the aid of a bipolar cautery. It is also carried out the application of mitomycin $0.02 \%$ soaked in flexible cotton swab, being in contact with the conjunctival surface injured for a period of 45 seconds.
After surgery (figure 4), eyedrops cyclosporine $0.05 \%$ was used for 15 days. Eyedrops loteprednol etabonate $(2.0 \mathrm{mg})$ is used topically as an adjunct to treatment ( 2 drops, $2 \mathrm{x} /$ day).

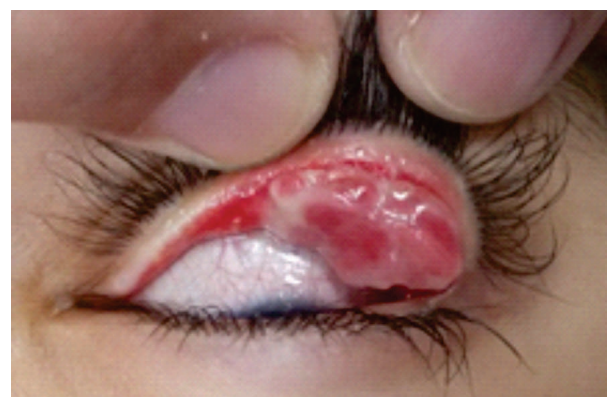

Figure 1: PG of the upper eyelid of the left eye

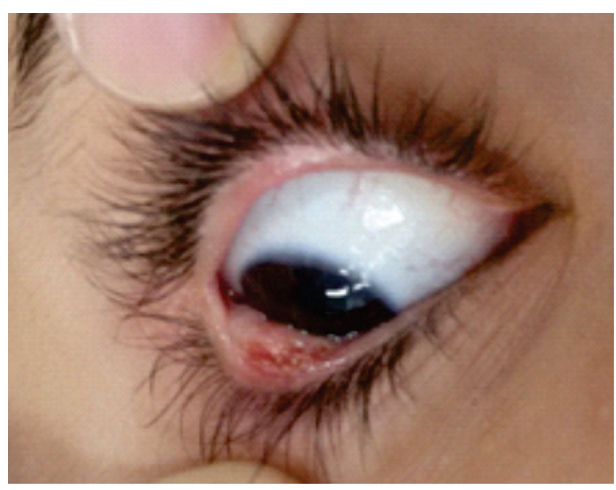

Figure 2: PG of the lower eyelid of the right eye

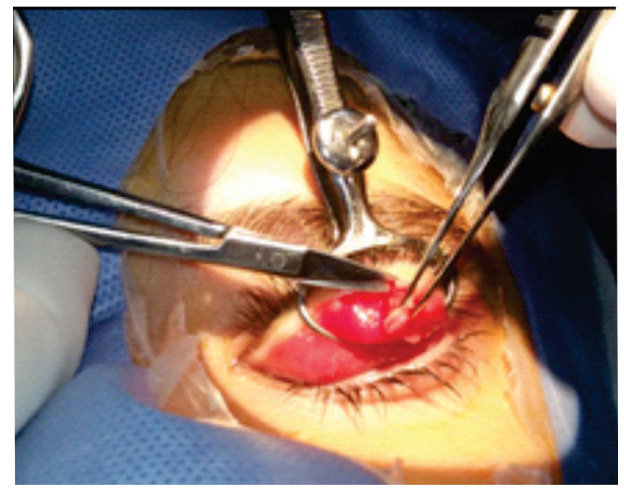

Figure 3: Surgery of the left upper eyelid

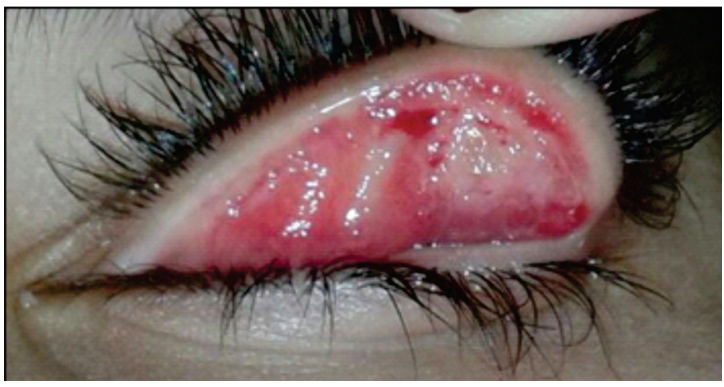

Figure 4: Pós-cirurgico da pálpebra superior do olho esquerdo (2 dias após a remoção) 
The histopathological analysis of the tissue removed carried out by the laboratory of the hospital where the surgery was performed showed acute inflammatory process in the Meibonium glands, with absence of malignancy.

\section{Literature Review}

Leagnous conjunctivitis (CL) is a rare pathology, without specific ethnic predilection. However, it is considered that it may have higher prevalence in areas where consanguinity is more common $^{[1,2]}$. PLs are deeply attached to the conjunctiva of the eyelid, and with its ends free. Removal tends to cause bleeding, because the area is vascularized. ${ }^{[4,5]}$

It is possible to observe the presence of mast cells and eosinophils in the lesions, which makes us believe that the secretions deposition would be by degranulation of these mast cells. It is understood that the massive extravasation of plasma constituents, fibrin in particular, ends up forming a kind of granuloma. ${ }^{[6]}$. In addition to the ocular region, other mucosas may be involved, such as oral, nasopharyngeal, gums, throat and vagina $^{[7,8]}$. Several cases of leagnous conjunctivitis and/or leagnous periodontitis were found in association with plasminogen deficiency type $\mathrm{I}^{[9,10]}$.

$\mathrm{CL}$ is caused by deficiency of plasminogen. It is linked to the dissolution of fibrin, and consequently, thrombus. When fibrin is not properly removed, it accumulates in the mucous tissues, creating a sort of leagnous pseudomembrane ${ }^{[2,3]}$. It plays an important role in the recruitment of macrophages during the inflammatory response, in invasion and metastasis of tumor cells, wound healing, tissue remodeling, growth of neurites and skeletal muscle tissue. ${ }^{[10,11]}$. The reference values vary according to the laboratory. In the present study, the reference value established was $70 \%$ to $140 \%$, as provided by the laboratory where the test was carried out.

Plasminogen deficiency is a rare autosomal recessive disease which can be asymptomatic heterozygous or symptomatic homozygous. It can be linked to the onset of low levels of plasminogen in children whose parents present reduced values $^{[12,13]}$. It can be classified in two ways: Type I (hipoplasminogenemia) or type II (displasminogenemia). The type I addressed in this study is characterized by great difficulty in healing, and has leagnous conjunctivitis as its main manifestation $^{[14]}$, but type II has thrombosis as the main risk ${ }^{[15]}$. Leagnous conjunctivitis is the most common presentation of clinical syndromes associated to plasminogen deficiency type $\mathrm{I}^{[1,2]}$.

The prevalence of this disease has not yet been established. The theoretical prevalence of homozygous or heterozygous (associated) patients was calculated as being of 1.6 by $1.000 .000 .^{[6]}$. However, other epidemiological studies are needed to better determine the prevalence of this deficiency. ${ }^{[2]}$.

In the literature, there are reports of surgery performed to remove PL, topical use of plasmin or plasminogen in the area ${ }^{[14,16]}$, immunosuppressants such as cyclosporine and heparin and positive autologous serum ${ }^{[5]}$ showing poor positive results. However, the granulomas returned at the end of the treatment. It should be noted that no treatment achieved the cure of the disease. The use of ophthalmologic concentrate of plasminogen and fresh frozen plasma systemically proved to be efficient, but are not accessible products to patients, not available on the market. ${ }^{[2]}$.

\section{Discussion}

The current literature is very scarce as to possible treatments to be carried out, none of them showing a possible cure for the disease, not even to alleviate the symptoms ${ }^{[2,5]}$.

The nutritional treatment after three years of treatment of phases 1 and 2 showed an increase of $25 \%$ in the dosage of plasminogen. This may not be highly significant at first, but gives support for further studies, because it shows improvement in the general condition of the patient, and can be related to this increase. This result was not found in any study in this literature ${ }^{[3]}$. Also, there was reduction in the production of mucus secretion after 15 days of administration of nutritional therapy for completion.

Regarding surgical treatment, it is palliative, because a few months after surgery there is recurrence of conjunctival membranes ${ }^{[2]}$. It was noted an increase in the interval between surgical procedures (from 3 months to1 year) that may have been related to the increase of the percentage rate of serum plasminogen.

Regarding the acute inflammatory process in the glands of Meibonium, studies show that this can have an effect on hormones such as estrogen ${ }^{[17]}$. Thus, it was speculated that this conjunctival lesion may have increased due to the influence of increased estrogen rate during puberty. Given the circumstance, a hormonal supplementation therapy started to further analyze the results generated.

\section{Conclusion}

The treatment reported is new in the literature because until then, no article presents increased organic production of plasminogen. This supports further studies in the area. It is necessary to continue to assess over time whether there will be a better patient response, and I suggest to seek alternatives to complement the treatment, aiming at better results.

\section{RefERenCES}

1. Kraft J, Lieb W, Zeitler P, Schuster V. Ligneous conjunctivitis in a girl with severe type I plasminogen deficiency. Graefes Arch Clin Exp Ophthalmol. 2000;238(9):797-800.

2. Mehta R, Shapiro AD. Plasminogen deficiency. Haemophilia. 2008;14(6):1261-8. Review.

3. Granito M, Schmidt B. Orthomolecular nutritional therapy for plasminogen deficiency: report of a case that showed positive results. Haemophilia. 2015;21(2):e139-41.

4. Holland EJ, Schwartz GS. Ligneous conjunctivis. In: Krachmer JH, Mannis MJ. Cornea and extrenal disease: clinical diagnosis and management. St. Louis: Mosby; 1997. 863-89.

5. Ang AY, Neff KD, Schwartz GS, Holland EJ. Conjuntivite lenhosa in: Holland EJ, Mannis MJ, Lee WD. Doenças da superfície ocular: Córnea, Conjuntiva e Filme Lacrimal. Elsevier, $1^{\circ} \mathrm{ed}$, Rio de Janeiro, 2013. p. 183-188.

6. Schuster V, Seregard S. Ligneous conjunctivitis. Surv Ophthalmol. 2003;48(4):369-88. Review.

7. Heinz C, Kremmer S, Externbrink P, Steuhl KP. [Ligneous conjunctivitis in a patient with plasminogen type I deficiency-case report with review of_literature]. Klin Monbl Augenheilkd. 2002;219(3):156-8. German. 
8. Tefs K, Gueorguieva M, Klammt J, Allen CM, Aktas D, Anlar FY,et al. Molecular and clinical spectrum of type I plasminogen deficiency: A series of 50 patients. Blood. 2006;108(9):3021-6..

9. El-Darouti M, Zayed AA, El-Kamah GY, Mostafa MI. Ligneous conjunctivitis with oral mucous membrane involvement and decreased plasminogen level. Pediatr Dermatol. 2009;26(4):448-51.

10. Yohe SL, Reyes M, Johnson DA, Fry CL, Scribbick FW, Kinney MC. Plasminogen deficiency as a rare cause of conjunctivitis and lymphadenopathy. Am J Surg Pathol. 2009 ;33(2):313-9.

11. Braunwald E, Zipes D, Libby P. Tratado de medicina cardiovascular. 6a ed. Rio de Janeiro: Roca; 2003

12. Miles LA, Plow EF, Waisman DM, Parmer RJ. Plasminogen receptors. J Biomed Biotechnol. 2012;2012:130735.

13. Lourenço DM. Trombofilia. In: Pitta GB, Castro AA, Burihan E. Angiologia e cirurgia vascular: guia ilustrado. Maceió: Uncisal/ Ecmal \& Lava; 2003.

14. Cohen J, Cohen S, Cymberknoh MC, Gross M, Hirshoren N, Shoseyov D. Laryngeal obstruction in congenital plasminogen deficiency. Pediatr Pulmonol. 2012;47(9):923-5.
15. Pergantou H, Likaki D, Fotopoulou M, Katsarou O, Xafaki P, Platokouki H. Management of ligneous conjunctivitis in a child with plasminogen deficiency. Eur J Pediatr. 2011;170(10):1333-6.

16. Schuster V, Hügle B, Tefs K. Plasminogen deficiency. J Thromb Haemost. 2007;5(12):2315-22.Review.

17. Heidemann DG, Williams GA, Hartzer M, Ohanian A, Citron ME. Treatment of ligneous conjunctivitis with topical plasmin and topical plasminogen. Cornea. 2003;22(8):760-2.

18. Del Castillo JM. Ojo seco. Granada: Tecnimedia; 1997.

\section{Corresponding author:}

João Maria Ferreira

Av. Alberto Torres, 111 - AltoTeresópolis, RJ, Brasil.

Phone.: (21) 2641-7128.

E-mail: clinoft@gmail.com 